\title{
TINJAUAN KELENGKAPAN PENGISISAN FORMULIR INFORMED CONSENT PADA PASIEN BEDAH RAWAT INAP DI RUMAH SAKIT SARI MULIA BANJARMASIN TRIWULAN KE-IV PADA TAHUN 2020

\author{
(Overview of the Completeness of Filling Out Informed Consent \\ Forms for Inpatient Surgical Patients at Sari Mulia Hospital, \\ Banjarmasin Fourth Quarter of 2020)
}

Muhammad Rashif Anshari, Putri Maisyarah, Risnawati

Program Studi DIII Perekam Medis dan Informasi Kesehatan

Politeknik Unggulan Kalimantan

Email : asip@polanka.ac.id

\begin{abstract}
The completeness of filling in informed consent is very important because it will affect the legal aspects of medical records and the quality of medical records so that in its implementation it must be carried out optimally. This study aims to determine the completeness of filling in informed consent for inpatient surgery patients in the fourth quarter of 2020 at Sari Mulia Hospital, Banjarmasin. This study uses descriptive quantitative research with a cross sectional research design, the method used is the observation method using a check list tool. In this study, the sampling technique was random sampling, the number of samples was 141 medical records of inpatient surgical patients analyzed, and all of them were still incomplete. The results obtained that the average number of completeness of filling based on identity review is $100 \%$, important note review is $46.8 \%$, authentication review is $90.7 \%$, good record review is $68 \%$. Where the highest completeness in the identity review is $100 \%$ and the lowest completeness is in the important note review, which is $46.8 \%$. Based on the results of the study, it can be concluded that the number of completeness of filling out informed consent forms for inpatient surgical patients at Sari Mulia Hospital Banjarmasin 4th Quarter of 2020 has not reached the SPM for medical records at hospital is $100 \%$.
\end{abstract}

Keywords: Informed Consent, Inpatient Patient, Identification Review, Important Records Review, Authentication Review, Good record review.

\section{ABSTRAK}

Kelengkapan pengisian infomed consent sangat penting karena akan mempengaruhi aspek hukum rekam medis dan mutu rekam medis sehingga dalam pelaksanaannya harus dilakukan secara maksimal. Penelitian ini bertujuan untuk mengetahui kelengkapan pengisian informed consent pasien bedah rawat inap Triwulan ke-IV Tahun 2020 di Rumah Sakit Sari Mulia Banjarmasin. Penelitian ini menggunakan penelitian kuantitatif deskriftif dengan rancangan penelitian cross sectional, metode yang digunakan adalah metode observasi dengan memakai alat bantu check list. Pada penelitian ini, teknik pengambilan sampel dengan random sampling, jumlah sampel ada 141 rekam medis pasien bedah rawat inap yang dianalisis, dan seluruhnya masih belum 
lengkap. Hasil penelitian diperoleh rata-rata angka kelengkapan pengisian berdasarkan review identitas $100 \%$, review catatan yang penting $46,8 \%$, review autentifikasi $90,7 \%$, review catatan yang baik $68 \%$. Dimana Kelengkapan tertinggi pada review identitas yaitu $100 \%$ dan kelengkapan terendah ada pada review catatan yang penting yaitu $46,8 \%$. Berdasarkan hasil penelitian dapat disimpulkan bahwa angka kelengkapan pengisian lembar informed consent pasien bedah rawat inap di Rumah Sakit Sari Mulia Banjarmasin Triwulan ke-IV Tahun 2020 belum mencapai SPM rekam medis di rumah sakit yaitu $100 \%$.

\section{Kata kunci: Informed Consent, Pasien Rawat Inap, Analisis Kuantitatif}

\section{PENDAHULUAN}

Undang-undang Nomor 44 Tahun 2009 pasal 1 ayat (1) mengatakan bahwa Rumah sakit adalah sarana kesehatan yang menyelenggarakan pelayanan kesehatan secara paripurna yang menyediakan pelayanan rawat inap, rawat jalan, dan gawat darurat. Agar rumah sakit dapat melaksanakan fungsi dengan baik, maka rumah sakit dituntut untuk memberikan pelayanan yang bermutu sesuai dengan standar yang telah ditetapkan. Salah satu yang berperan penting dalam suatu rumah sakit adalah bagian dari intalasi rekam medis yang disebut dengan medical record.

Rekam medis menurut Peraturan Menteri Kesehatan No: 269/MENKES/PER/III/2008 Pasal 1 Ayat (1) adalah berkas yang berisi catatan dan dokumen mengenai identitas pasien, hasil pemeriksaan, pengobatan, serta tindakan dan pelayanan lain yang diberikan kepada pasien. Rekam medis terdiri dari kumpulan formulir yang memiliki fungsi berbeda dan dianggap penting, salah satunya yaitu formulir persetujuan tindakan medis (informed consent).

Peraturan Menteri Kesehatan No. 290/MENKES/PER/III/2008 Pasal 1 ayat (1) mengatakan bahwa yang dimaksud persetujuan tindakan medis (informed consent) adalah persetujuan yang diberikan oleh pasien atau keluarga terdekat setelah mendapat penjelasan secara lengkap mengenai tindakan medis yang akan dilakukan terhadap pasien. Salah satunya yaitu tindakan pembedahan. Informed consent dapat dijadikan alat bukti hukum, apabila terjadi gugatan atas kesalahan tindakan kedokteran. Pengisian persetujuan yang dilakukan pasien atau keluarga pasien dan dokter dalam informed consent menjadi alat bukti yang sah sebagai upaya untuk pencegahan dari tuntutan hukum.

Peraturan Menteri Kesehatan No. 290 Tahun 2008 Pasal 7 ayat (3) menerangkan bahwa penulisan dan penjelasan informed consent sekurang-kurangnya mencakup diagnosis, tata cara tindakan kedokteran, tujuan tindakan medis yang dilakukan, alternatif tindakan lain dan resikonya, Komplikasi yang mungkin akan terjadi, dan prognosis terhadap tindakan yang dilakukan. Kelengkapan pengisian informed consent sangat penting karena akan mempengaruhi aspek hukum rekam medis dan mutu rekam medis sehingga dalam pengisian kelengkapan data dalam lembar informed

consent perlu dilakukan dengan pelaksanaan yang maksimal (Samosir, 2017). Menurut Kementerian Kesehatan Tahun 2008 dalam penelitian (Rusdiana, 2017) menyebutkan bahwa salah satu SPM rekam medis di rumah sakit tentang kewajiban kelengkapan informed consent setelah mendapatkan informasi yang jelas sebesar $100 \%$.

Penelitian Rusdiana, Ahyar (2017), mengatakan bahwa hasil rekapitulasi dari empat komponen analisis kuantitatif informed consent pasien bedah rawat inap di Rumah Sakit 
Umum Pusat Persahabatan dalam pengisian hanya 69,87\% dan yang tidak lengkap ada $29,94 \%$. Dalam pengisian masih belum cukup konsisten, tepat dan akurat karena masih banyak yang kurang memperhatikan pengisian informed consent sesuai Standar Operasional Prosedur (SOP) yang ada.

Berdasarkan hasil studi pendahuluan pada tanggal 2 Desember tahun 2020 di sub bagian Rekam medis Rumah Sakit Sari Mulia Banjarmasin, didapatkan 65 dokumen rekam medis pasien bedah rawat inap pada bulan Oktober tahun 2020. Peneliti mengambil 20 dokumen rekam medis untuk dianalisis. Dari 20 sampel dokumen terdapat 6 dokumen (30\%) yang tidak terisi lengkap, dan 14 dokumen (70\%) yang terisi lengkap. Ketidaklengkapan pengisian informed consent yang ditemukan diantaranya ada 2 dokumen di bagian autentifikasi khususnya pada nama dokter, dan 4 dokumen di bagian informasi tindakan, khususnya bagian isi informasi yang sama sekali tidak diisi atau kosong. Berdasarkan latar belakang tersebut, maka peneliti tertarik untuk mengangkat judul penelitian tentang "Tinjauan Kelengkapan Pengisian Formulir Informed Consent pada Pasien Bedah Rawat Inap di Rumah Sakit Sari Mulia Banjarmasin Triwulan ke-IV padaTahun 2020".

\section{METODE PENELITIAN}

Jenis penelitian yang digunakan dalam penelitian ini adalah kuantitatif. Rancangan penelitian yang di gunakan adalah cross sectional. Variabel penelitian yaitu, Mengidentifikasi kelengkapan pengisian informed consent berdasarkan identifikasi pasien, berdasarkan review catatan yang penting, berdasarkan autentifikasi dan berdasarkan catatan yang baik. Tempat penelitian yaitu Rumah Sakit Sari Mulia Banjarmasin data yang diteliti diambil dari bulan oktober, november dan Desember Tahun 2020. Dengan jumlah populasi 218 dan sampel 141. Dalam memilih sampel menggunakan teknik random sampling. Metode pengumpulan data yaitu observasi dengan lembar checklist analisis kuantitatif. Analisis Formulir informed consent pasien bedah rawat inap menggunakan review kuantitatif.

\section{HASIL DAN PEMBAHASAN}

Berikut adalah hasil sekaligus pembahasan penelitian yang terdiri dari 4 komponen yaitu; review identitas, review catatan yang penting, review autentifikasi, review catatan yang penting.

\section{Mengidentifikasi kelengkapan pengisian informed consent pasien bedah rawat inap berdasarkan review identitas}

Tabel 1. Hasil Analisis Kuantitatif Kelengkapan Pengisian Informed Consent Pasien Bedah Rawat Inap Berdasarkan Review Identitas Di Rumah Sakit Sari Mulia Banjarmasin Triwulan IV Tahun 2020

\begin{tabular}{|c|c|c|c|c|c|c|}
\hline \multirow{2}{*}{ No } & \multirow{2}{*}{$\begin{array}{c}\text { Review identitas } \\
\text { pasien }\end{array}$} & \multicolumn{2}{|c|}{ L } & \multicolumn{2}{|c|}{$\begin{array}{c}\text { Jumlah } \\
\text { Form }\end{array}$} \\
\cline { 3 - 6 } & Jumlah & Persen & Jumlah & Persen & 141 \\
\hline 1 & Nama & 141 & $100 \%$ & 141 & $100 \%$ & 141 \\
\hline 2 & No RM & 141 & $100 \%$ & 141 & $100 \%$ & 141 \\
\hline 3 & Tanggal lahir & 141 & $100 \%$ & 141 & $100 \%$ & 141 \\
\hline 4 & Jenis kelamin & 141 & $100 \%$ & 141 & $100 \%$ & 141 \\
\hline
\end{tabular}




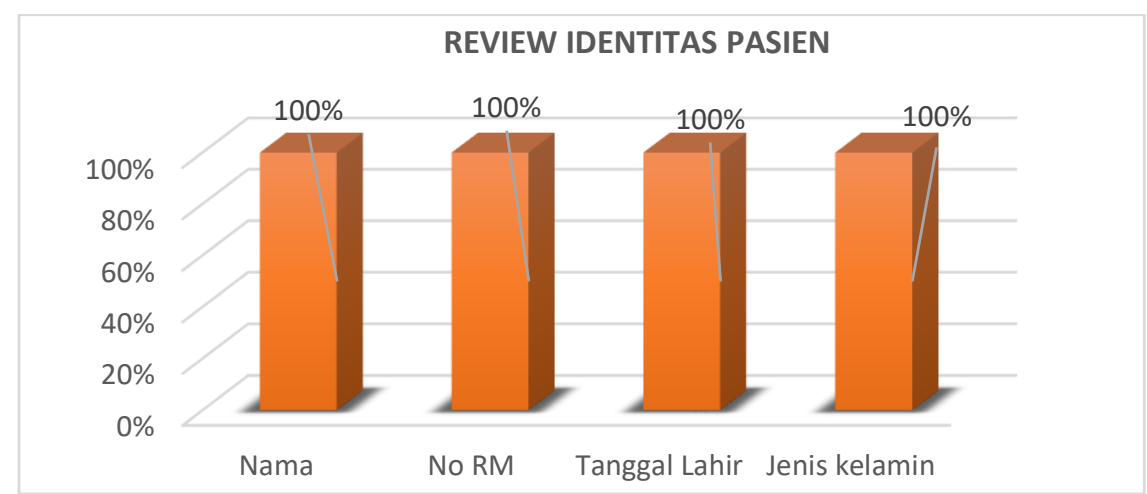

Gambar 1. Grafik review identitas pasien pengisian informed consent pasien bedah rawat inap Triwulan IV Tahun 2020 di Rumah Sakit Sari Mulia Banjarmasin

Dilihat dari Tabel 1 dan Gambar 1 diatas yang menunjukan bahwa kelengkapan pengisian informed consent pasien bedah rawat inap Triwulan IV Tahun 2020 berdasarkan review identitas sudah terisi lengkap 100\%. Hal ini dikarenakan Rumah Sakit Sari Mulia Banjarmasin dalam pengisian identitas pasien sudah menggunakan stiker. Penggunaan stiker label pasien ini sangat menguntungkan karena pemberi pelayanan tidak perlu menulis, tinggal menempelkan pada bagian tertentu dari tiap formulir.

\section{Mengidentifikasi kelengkapan pengisian informed consent pasien bedah rawat inap berdasarkan review catatan yang penting}

Tabel 2. Hasil Analisis Kuantitatif Kelengkapan Pengisian Informed Consent Pasien Bedah Rawat Inap Berdasarkan Review Catatan Yang Penting Di Rumah Sakit Sari Mulia Banjarmasin Triwulan IV Tahun 2020

\begin{tabular}{|c|c|c|c|c|c|c|}
\hline \multirow{2}{*}{ No } & \multirow{2}{*}{$\begin{array}{c}\text { Review catatan yang } \\
\text { penting }\end{array}$} & \multicolumn{2}{|c|}{$\mathbf{L}$} & \multicolumn{2}{|c|}{ TL } & \multirow{2}{*}{$\begin{array}{c}\text { Jumlah } \\
\text { Form }\end{array}$} \\
\cline { 3 - 5 } & Jumlah & Persen & Jumlah & Persen & 141 \\
\hline 1 & Diagnosis & 105 & $74,4 \%$ & 36 & $25,5 \%$ & 141 \\
\hline 2 & Dasar diagnosis & 95 & $67,3 \%$ & 46 & $32,6 \%$ & 141 \\
\hline 3 & Tindakan kedokteran & 88 & $62,4 \%$ & 53 & $37,6 \%$ & 141 \\
\hline 4 & Indikasi tindakan & 91 & $64,5 \%$ & 50 & $35,5 \%$ & 141 \\
\hline 5 & Tata cara & 83 & $58,8 \%$ & 58 & $41,2 \%$ & 141 \\
\hline 6 & Tujuan & 68 & $48,2 \%$ & 73 & $51,8 \%$ & 141 \\
\hline 7 & Resiko & 77 & $54,6 \%$ & 64 & $45,4 \%$ & 141 \\
\hline 8 & Komplikasi & 57 & $40,4 \%$ & 84 & $59,6 \%$ & 141 \\
\hline 9 & Prognosis & 58 & $41,1 \%$ & 83 & $58,9 \%$ & 141 \\
\hline 10 & Alternatife \& resiko & 32 & $22,6 \%$ & 109 & $77,4 \%$ & 141 \\
\hline 11 & Resiko kehilangan darah & 22 & $15,6 \%$ & 119 & $84,4 \%$ & 141 \\
\hline 12 & Lain-lain & 17 & $12 \%$ & 124 & $88 \%$ & 141 \\
\hline & Rata-rata & 66 & $46,8 \%$ & 75 & $53,2 \%$ & \\
\hline
\end{tabular}




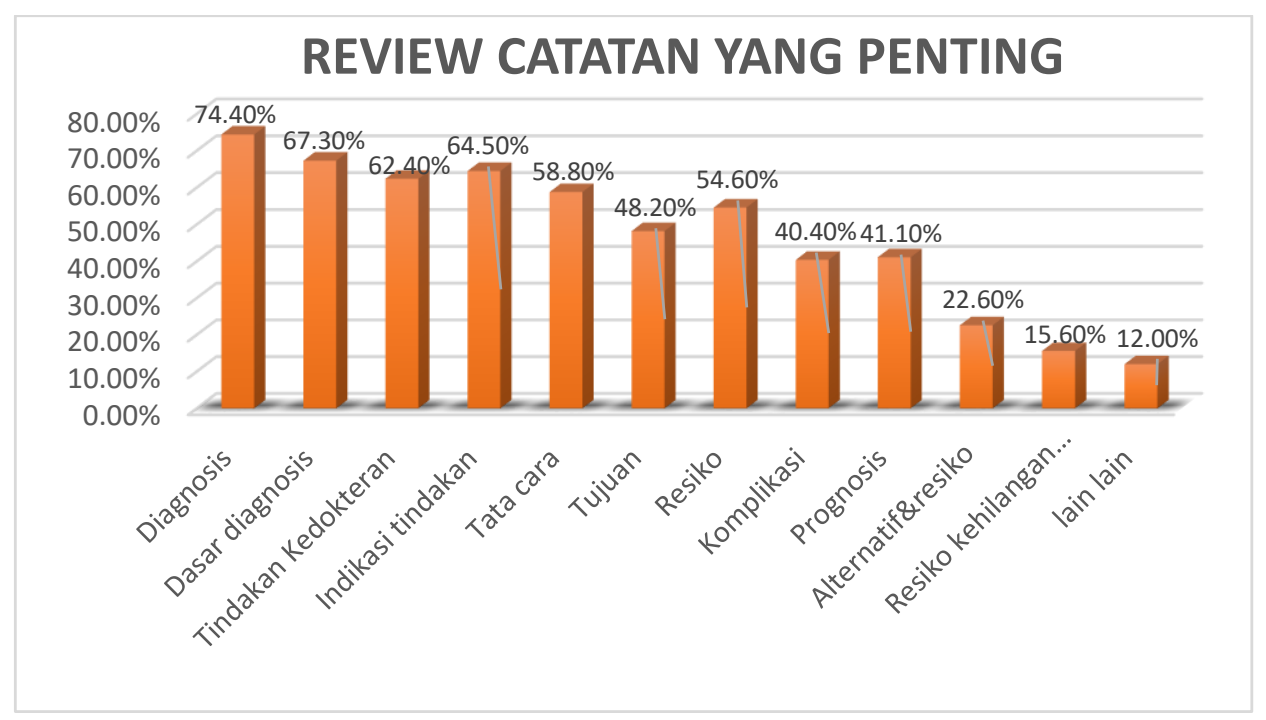

Gambar 2. Grafik Review Catatan Yang Penting Pengisian Informed Consent Pasien Bedah Rawat Inap Triwulan IV Tahun 2020 Di Rumah Sakit Sari Mulia Banjarmasin

Dilihat dari Tabel 2 dan Gambar 2 diatas yang menunjukan bahwa kelengkapan pengisian informed consent pasien bedah rawat inap Triwulan IV tahun 2020 berdasarkan review catatan yang penting masih tidak terisi lengkap. Rata-rata pengisian hanya mencapai $46,8 \%$, dan pengisian tertinggi hanya $74,4 \%$. Menurut Peraturan Menteri Kesehatan No. 290 Tahun 2008 Pasal 7 ayat (3) dan Undangundang No. 29 Tahun 2004 Pasal 45 Ayat 3 menerangkan bahwa penulisan dan penjelasan informed consent sekurang-kurangnya mencakup diagnosis, tata cara tindakan kedokteran, tujuan tindakan medis yang dilakukan, alternatif tindakan lain dan resikonya, Komplikasi yang mungkin akan terjadi, dan prognosis terhadap tindakan yang dilakukan.

Berdasarkan hasil identifikasi kelengkapan pengisian informed consent pasien bedah rawat inap yang dilakukan oleh peneliti di Rumah Sakit Sari Mulia Banjarmasin dari komponen review catatan yang penting rata-rata kelengkapan pada review catatan penting ini hanya $46,8 \%$ dan kelengkapan paling tinggi hanya mencapai $74,40 \%$ yang ada pada komponen diagnosis. Sedangkan kelengkapan pengisian terendah berturut-turut ada pada komponen alternatif dan resiko yang mencapai $22,60 \%$, resiko kehilangan darah/transfuse darah yang mencapai $15,60 \%$. Dan yang terakhir ada di komponen lain-lain sebesar $12 \%$.

Alternatif dan resiko merupakan komponen yang berisi alternatif Tindakan lain yang akan dilakukan Dokter beserta resikonya. Kemudian untuk resiko kehilangan darah merupakan komponen resiko kehilangan darah/rencana tranfusi darah jika pasien membutuhkan (situational). Sedangkan untuk komponen lain-lain bersifat situational sesuai prediksi dokter diluar dari kolom yang ada. Ada beberapa pasien yang bersifat situational, seperti tidak ada resiko kehilangan darah, dan tidak ada alternatif Tindakan beserta resikonya. Untuk menindak lanjuti hal ini seharusnya formulir jangan dibiarkan kosong. Gunakanlah tanda (-) yang menandakan bahwa pasien tidak memiliki resiko kehilangan darah, dan tidak ada alternatif Tindakan yang dilakukan. Hal ini dilakukan agar membuat formulir terisi dan tidak dianggap kosong. Sesuai dengan teori (Lily Widjaya, 2018) yang mengatakan bahwa bagian yang tidak perlu diisi, wajib diberi tanda "-“. Hal ini bisa dinilai terisinya suatu formulir. Dan jika tidak diberi tanda seakan-akan belum diisi lengkap. 
Namun pada kenyataannya beberapa lembar informed consent tetap kosong tidak berisi symbol apalagi catatan. Rendahnya kelengkapan pada komponen catatan yang penting tidak menyebabkan pengaruh secara langsung terhadap mutu pelayanan, akan tetapi kelengkapan informed consent sangat penting dan dapat digunakan sebagai alat bukti hukum yang sah yaitu bukti tertulis oleh rumah sakit bahwa Dokter telah memberikan tindakan kedokteran, tindakan medis serta perawatan kepada pasien.

Berdasarkan penelitian (Ulfa, 2018) kelengkapan pengisian jenis informasi yang tertinggi yaitu Indikasi tindakan sebesar $90 \%$ dan yang terendah yaitu tujuan sebesar $60 \%$. Hal ini dikarenakan keterbatasan sumber daya manusia di Unit Rekam Medis Rumah Sakit Sansani. Berdasarkan penelitian (Suharto, 2017) Tidak lengkapnya pengisian item laporan operasi dikarenakan kebiasaan dan kurangnya kesadaran dari Dokter atau Perawat yang tidak mengisi laporan operasi setiap selesai dalam pelayanan terhadap pasien.

Berdasarkan penelitian (Meyyulinar, 2019) faktor-faktor yang menyebabkan ketidaklengkapan pengisian lembar informed consent di RS.AL Marinir Cilanda adalah rendahnya pemahaman dokter tentang pentingnya informed consent, keterbatasan waktu praktek dokter, kesibukan dokter yang bisa melakukan 5 kali operasi dalam sehari, kurangnya perhatian Dokter dalam mengisi persetujuan tindakan (informed consent), karena Dokter lebih mementingkan dalam memberikan pelayanan terhadap pasien daripada untuk memikirkan kepentingan administratifnya.

\section{Mengidentifikasi kelengkapan pengisian informed consent pasien bedah rawat inap berdasarkan review autentifikasi}

Tabel 3. Hasil Analisis Kuantitatif Kelengkapan Pengisian Informed Consent Pasien Bedah Rawat Inap Berdasarkan Review Autentifikasi Di Rumah Sakit Sari Mulia Banjarmasin Triwulan IV (Oktober-November-Desember) Tahun 2020

\begin{tabular}{|c|c|c|c|c|c|c|}
\hline \multirow[t]{2}{*}{ No } & \multirow[t]{2}{*}{ Review autentifikasi } & \multicolumn{2}{|c|}{$\mathbf{L}$} & \multicolumn{2}{|c|}{ TL } & \multirow{2}{*}{$\begin{array}{c}\text { Jumlah } \\
\text { Form }\end{array}$} \\
\hline & & Jumlah & Persen & Jumlah & Persen & \\
\hline 1 & $\begin{array}{c}\text { Tanda tangan wali / } \\
\text { pasien }\end{array}$ & 130 & $92,1 \%$ & 11 & $7,9 \%$ & 141 \\
\hline 2 & Nama wali/ pasien & 137 & $97,1 \%$ & 4 & $2,9 \%$ & 141 \\
\hline 3 & Tanda tangan dokter & 128 & $90,7 \%$ & 13 & $9,3 \%$ & 141 \\
\hline 4 & Nama dokter & 119 & $84,3 \%$ & 22 & $15,7 \%$ & 141 \\
\hline 5 & Tanda tangan perawat & 137 & $97,1 \%$ & 4 & $2,9 \%$ & 141 \\
\hline 6 & Nama perawat & 136 & $96,4 \%$ & 5 & $3,6 \%$ & 141 \\
\hline 7 & Tanda tangan saksi I & 132 & $93,6 \%$ & 9 & $6,4 \%$ & 141 \\
\hline 8 & Nama saksi I & 126 & $89,3 \%$ & 15 & $10,7 \%$ & 141 \\
\hline 9 & Tanda tangan Saksi II & 121 & $85,8 \%$ & 20 & $14,2 \%$ & 141 \\
\hline 10 & Nama sakisi II & 114 & $80,8 \%$ & 27 & $19,2 \%$ & 141 \\
\hline & Rata-rata & 128 & $90,7 \%$ & 13 & $9,3 \%$ & 141 \\
\hline
\end{tabular}




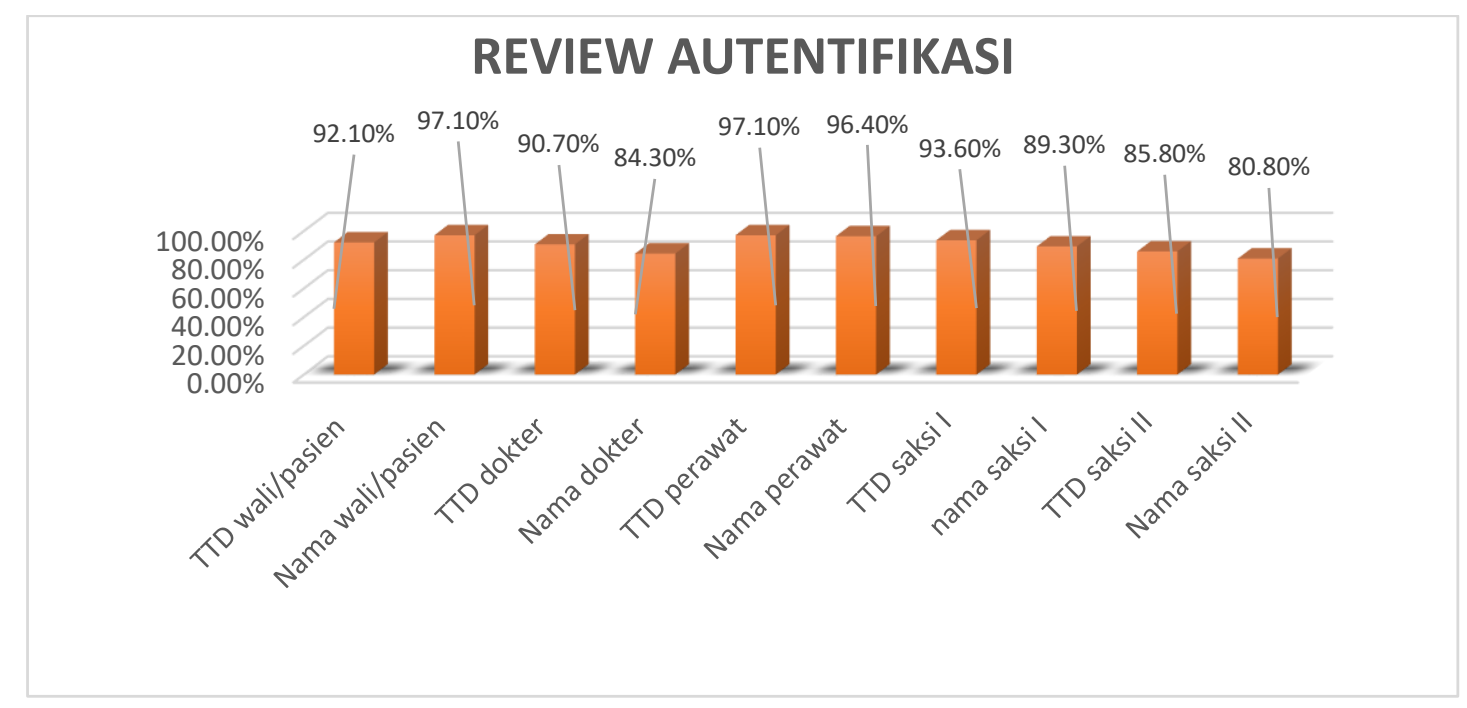

Gambar 3. Grafik Review Autentifikasi Pengisian Informed Consent Pasien Bedah Rawat Inap Triwulan IV Tahun 2020 Di Rumah Sakit Sari Mulia Banjarmasin

Dilihat dari Tabel 3 dan Gambar 3, menunjukan bahwa kelengkapan pengisian informed consent pasien bedah rawat inap Triwulan IV Tahun 2020 berdasarkan review autentifikasi tidak terisi lengkap. Rata-rata pengisian hanya 90,7\% dengan pengisian paling tinggi sebesar 97,1\%. Menurut Undang-undang Nomor 29 Tahun 2004 Pasal 46 ayat 3, Peraturan Menteri Kesehatan No. 269/MENKES/PER/III/2008 pasal 5, dan Peraturan Menteri Kesehatan No. 290 tahun 2008 pasal 9 ayat 2 mengatakan bahwa setiap catatan rekam medis harus dibubuhi nama, waktu dan tanda tangan petugas yang memberikan pelayanan atau Tindakan secara langsung. Pembubuhan nama dan tanda tangan ini perlu diperhatikan karena setiap petugas yang mencatumkan nama dan tanda tangan pada rekam medis tersebut bertanggung jawab penuh atas isi rekam medis yang ditandatangani. Kemudian berdasarkan penelitian Pamungkasari (2018) mengatakan bahwa format pengisian informed consent yaitu harus diketahui dan di tanda tangani oleh dua orang saksi. Dimana perawat bertindak sebagai salah satu saksi. Kemudian juga dikatakan bahwa formulir informed consent harus sudah diisi dan ditanda-tangani 24 jam sebelum Tindakan medis.

Berdasarkan hasil identifikasi kelengkapan pengisian informed consent pasien bedah rawat inap yang dilakukan oleh peneliti di Rumah Sakit Sari Mulia Banjarmasin dari komponen review autentifikasi rata-rata pengisian sebesar 90,7\%. Pengisian tertinggi sebesar $97,10 \%$ terdapat pada komponen tanda tangan perawat dan nama wali/pasien. Sedangkan kelengkapan pengisian terendah berturut-turut ada pada komponen Tanda tangan dan Nama Saksi Il sebesar 85,80\% dan 80,80\% serta Nama Dokter sebesar $84,30 \%$. Dilihat dari persentasi kelengkapan masih ada dokter dan saksi yang melupakan pengisian nama dan tanda tangan di lembar informed consent. Seharusnya rekam medis yang sudah ada didalam ruang filing sudah terisi lengkap. Namun, faktanya rekam medis yang ada di ruang filing khususnya autentifikasi pada lembar informed consent masih ada yang belum terisi lengkap.

Untuk menindak lanjuti ketidaklengkapan dari Tanda Tangan dan Nama Saksi II serta Nama Dokter bisa meminta bantuan perawat untuk mengecek kembali 
komponen autentifikasi pada lembar informed consent dan melengkapinya. Seperti Membantu Dokter yang lupa menstempelkan namanya, dengan menggunakan stempel nama Dokter, serta memberitahukan kepada wali pasien untuk wajib menghadirkan saksi dari pihak keluarga untuk memberi tanda tangan. Berdasarkan penelitian Suharto (2017), ketidaklengkapan pengisian autentifikasi karena disebabkan tenaga kesehatan belum melaksanakan tertib administrasi dengan baik dan tidak ada bukti bahwa dokter telah memberikan informasi mengenai tindakan medis yang dilakukan oleh pasien.

4. Mengidentifikasi kelengkapan pengisian informed consent pasien bedah rawat inap berdasarkan review catatan yang baik

Tabel 4. Hasil Analisis Kuantitatif Kelengkapan Pengisian Informed Consent Pasien Bedah Rawat Inap Berdasarkan Review Catatan Yang Baik Di Rumah Sakit Sari Mulia Banjarmasin Triwulan IV (Oktober-November-Desember) Tahun 2020

\begin{tabular}{|c|c|c|c|c|c|c|}
\hline \multirow{2}{*}{ No } & \multirow{2}{*}{ Review catatan yang baik } & \multicolumn{2}{|c|}{ L } & \multicolumn{2}{|c|}{ TL } & \multirow{2}{*}{\begin{tabular}{c} 
Jumlah \\
\cline { 3 - 5 }
\end{tabular}} \\
\cline { 3 - 5 } & Jumlah & Persen & Jumlah & Persen & 141 \\
\hline 1 & Tidak ada coretan & 135 & $95,7 \%$ & 6 & $4,3 \%$ & 141 \\
\hline 2 & Tidak ada tip-ex & 141 & $100 \%$ & 0 & $0 \%$ & 141 \\
\hline 3 & Tidak ada yang kosong & 12 & $8,5 \%$ & 129 & $91,5 \%$ & 141 \\
\hline 4 & Rata rata & 96 & $68 \%$ & 45 & $32 \%$ & 1 \\
\hline
\end{tabular}

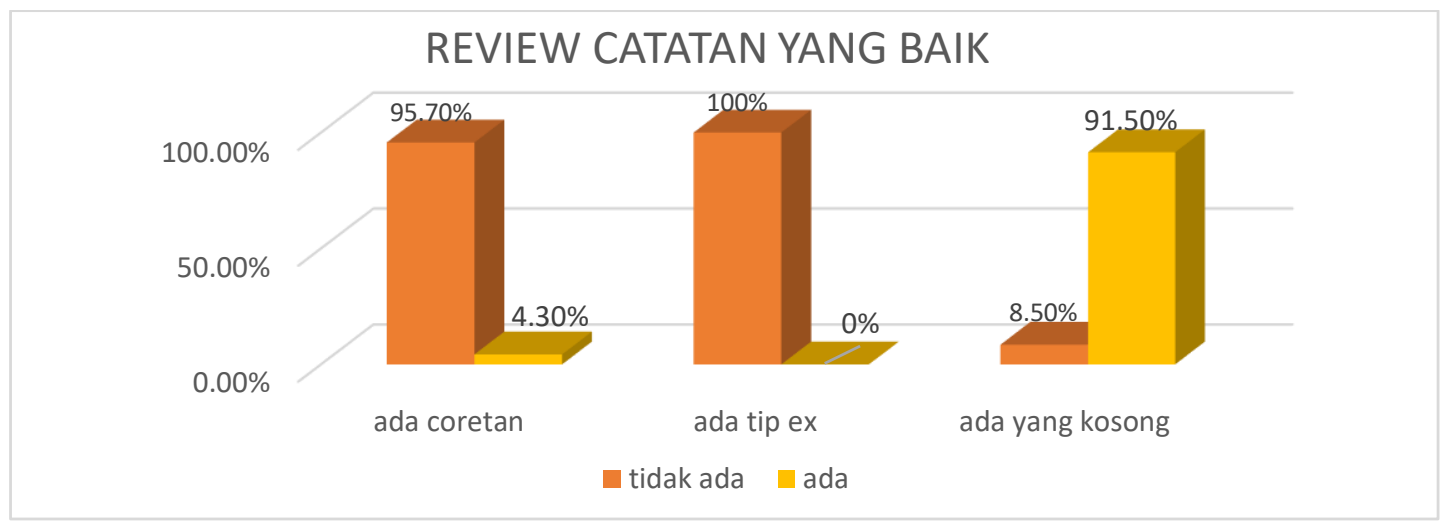

Gambar 4. Grafik Review Catatan Yang Baik Pengisian Informed Consent Pasien Bedah Rawat Inap Triwulan IV Tahun 2020 Di Rumah Sakit Sari Mulia Banjarmasin

Dilihat dari Tabel 4 dan Gambar 4 diatas, menunjukan bahwa kelengkapan pengisian informed consent pasien bedah rawat inap Triwulan IV berdasarkan review catatan yang baik tidak terisi lengkap. Hal ini dikarenakan masih banyak informed consent yang kosong yaitu sebesar $91,5 \%$. Kelengkapan pengisian berdasarkan pencatatan yang baik dapat dilihat dari tidak boleh ada coretan, tidak boleh ada penghapusan tulisan dengan tip-ex ataupun penghapus lainnya, dan tidak boleh ada bagian yang tidak diisi (Lily Widjaya, 2018). Menurut Peraturan Menteri Kesehatan No. 269 Tahun 2008 Pasal 5 Ayat 5 dan 6 mengatakan bahwa jika terjadi kesalahan dalam pencatatan rekam medis maka dapat dilakukan pembetulan. Pembetulan hanya dapat dilakukan dengan cara mencoret, tanpa menghilangkan catatan yang dibetulkan. Kemudian diberi paraf dokter, dokter gigi atau tenaga kesehatan tertentu 
yang bersangkutan. Peraturan Menteri Kesehatan No.129 Tahun 2008 tentang standar pelayanan minimal rumah sakit menyebutkan bahwa kelengkapan informed consent wajib terisi $100 \%$.

Berdasarkan hasil identifikasi kelengkapan pengisian informed consent pasien bedah rawat inap yang dilakukan oleh peneliti di Rumah Sakit Sari Mulia Banjarmasin dari komponen review catatan yang baik rata-rata pengisian sebesar $68 \%$. Dari seluruh sampel tidak terdapat tip-ex $100 \%$. Namun terdapat coretan sebesar $4,3 \%$. Serta masih banyak catatan yang kosong/tidak terisi yaitu $91,5 \%$. Dari data tersebut dapat dikatakan bahwa masih banyak pasien/keluarga pasien dan tenaga medis lainnya yang tidak mengisi formulir informed consent dengan lengkap. Dan masih ada beberapa petugas yang tidak tahu jika terjadi kesalahan dalam penulisan wajib dicoret satu kali dan di paraf, yang berarti tidak boleh dicoret-coret sehingga penulisan tidak bisa dibaca. Hal ini nantinya, akan di "Sangka" menghilangkan data yang merupakan bukti pelayanan yang salah. Bagian yang kosong, lebih banyak pada bagian isi informasi (komponen catatan yang penting). Untuk mengatasi hal ini sebaiknya perlu dimuat lagi dalam SOP pengisian informed consent mengenai penggunaan tanda (-) jika bagian tersebut tidak perlu diisi, sehingga formulir informed consent tidak terlihat kosong. Serta cara pencoretan yang benar dengan mencoret satu kali kemudian di paraf.

Berdasarkan penelitian (Suharto, 2017) Hasil dari penelitian ini ditemukan ada beberapa formulir Persetujuan Tindakan Kedokteran (informed consent) yang tidak terisi pada item data pencatatan berupa coretan (14,28\%) dan singkatan (11,22\%). Ketidaksesuaian pencatatan tersebut karena kebiasaan dan kurangnya kesadaran dari dokter maupun petugas medis yang bertanggung jawab dalam melakukan pengisian dokumen rekam medis setiap selesai. 


\section{Mengidentifikasi standar Operasional Prosesdur (SOP) pengisian informed consent di Rumah Sakit Sari Mulia Banjarmasin}

Berdasarkan hasil observasi untuk Standar Operasional Prosedur pengisian persetujuan tindakan kedokteran sudah ada dan juga sudah disosialisasikan kepada para tenaga medis yang berkaitan seperti dokter dan perawat. Tetapi masih banyak yang kurang menyadari akan tanggung jawabnya dalam pengisian, sehingga banyak yang belum terisi lengkap dan kosong. Untuk menindak lanjutinya, Sebaiknya perlu dimuat lagi pada SOP dibagian Hal yang perlu diperhatikan ditambah 2 poin yaitu d. jika ada bagian Tindakan yang tidak perlu diisi gunakan tanda (-). Dan poin e. jika ada kesalahan dalam penulisan coret sekali lalu paraf.

Berdasarkan hasil penelitian maka kelengkapan pengisian informed consent pasien bedah rawat inap di Rumah Sakit Sari Mulia Banjarmasin Triwulan IV Tahun 2020 ada lebih dari 75\% yaitu kelengkapan berdasarkan review identitas 100\%, dan review autentifikasi sebesar 90,7\%. Kelengkapan pengisian juga masih ada yang kurang dari $75 \%$ seperti review catatan yang penting $46,8 \%$, dan review catatan yang baik $68 \%$.

\section{KESIMPULAN}

Berdasarkan hasil penelitian kelengkapan pengisian Informed consent pasien bedah rawat inap di Rumah Sakit Sari Mulia Banjarmasin diketahui persentasi nya sebagai berikut:

1. Kelengkapan pengisian informed consent pasien bedah rawat inap Triwulan-IV Tahun 2020 berdasarkan Review identitas sudah terisi lengkap. Hal ini dibuktikan dengan hasil penelitian saya yaitu $100 \%$.

2. Kelengkapan pengisian informed consent pasien bedah rawat inap Triwulan-IV Tahun 2020 berdasarkan Review catatan yang penting belum terisi lengkap. Hal ini dibuktikan dengan hasil penelitian saya, yaitu $46,8 \%$

3. Kelengkapan pengisian informed consent pasien bedah rawat inap Triwulan-IV Tahun 2020 berdasarkan review autentifikasi belum terisi lengkap. Hal ini dibuktikan dengan hasil penelitian saya yaitu $90,7 \%$

4. Kelengkapan pengisian informed consent pasien bedah rawat inap Triwulan-IV Tahun 2020 berdasarkan review catatan yang baik belum terisi lengkap. Hal ini dibuktikan dengan hasil penelitian saya yaitu $68 \%$.

5. SOP pengisian informed consent di Rumah Sakit Sari Mulia Banjarmasin sudah ada dan juga sudah di sosialisasikan kepada para tenaga medis yang berkaitan seperti dokter dan perawat.

\section{DAFTAR PUSTAKA}

Achmad Busro. (2018). Aspek Hukum Persetujuan Tindakan Medis (informed consent) Dalam Pelayanan Kesehatan. Vol 1, No 1 (2018): Law \& Justice Journal

Arifin, R. B. (2015). Asuhan Keperawatan Pada Klien dengan Benigna Prostat Hiperlapsia Post Open Prostatectomi Hari ke 1 di Ruang Gladiol atas RSUD Sukoharjo . 1.

Dr. Bekti Suharto. (2017). Tinjauan Ketidaklengkapan Formulir Persetujuan Tindakan Kedokteran Pada Pasien Rawat Inap Dari Aspek Hukum di RSUD dr. Soediran Mangun Sumarso Kabupaten Wonogiri. IJMS - Indonesian Journal On Medical Science - Volume 4 No 2

Dr. Eti Poncorini Pamungkasari, dr., MPd. Rohmaningtyas HS, dr., Sp.KJ. Dr. Veronika Ika B, dr., MPd. Debree Septiawan, dr., Sp.KJ. Amandha Boy Timor R, dr., M.Med.Ed. (2018). Buku Manual Keterampilan Klinik Topik Persetujuan Tindakan Kedokteran (Informed Consent). Surakarta: Universitas Kedokteran Universitas Sebelas Maret.

Dr. Hasmi, S. M. (2016). Metode Penelitian Kesehatan . Penerbit In Media. 
Departemen Kesehatan RI, Peraturan Menteri Kesehatan Nomor 269/MENKES/PER/II/2008 tentang rekam medis, Jakarta : Departemen Kesehatan RI

Departemen Kesehatan RI, Peraturan Menteri Kesehatan Nomor 290/MENKES/PER/II/2008 tentang Persetujuan Tindakan Kedokteran, Jakarta : Departemen Kesehatan RI

Dewi Oktavia, Hardisman, Erkadius. (2020) Analsisis ketidaklengkapan pengisian lembar informed consent pasien bedah di rumah sakit Tk.III dr. Reksodiwiryo Padang. Jurnal Manajemen Informasi Kesehatan Indonesia Vol. 8 No.1

Gabriele. (2018). Analisis Penerapan Standar Operasional (SOP) di Departemen Marketing dan HRD . PT Cahaya Indo Persada Vol 6 No 1 Tahun 2018.

Henny Maria Ulfa. (2018). Analisa Kelengkapan Informed Consent Tindakan Operasi di Rumah Sakit Sansani Pekanbaru. Jurnal INOHIM, Volume 6 Nomor 1

Lily Widjaya, S. (2018). Manajemen Mutu Informasi Kesehatan III Pendokumentasian Rekam Medis . Indonesia : Kementerian Kesehatan Rebulik Indonesia .

Meyyulinar, H. (2019). Analisis Faktor- Faktor Penyebab Ketidaklengkapan Informed Consent Pada Kasus Bedah Di Rumah Sakit AL Marinir Cilandak. Jurnal Manajemen dan Administrasi Rumah Sakit Indonesia Vol 3.

Notoatmodjo, S. (2012). Metodologi Penelitian Kesehatan Edisi Revisi. Jakarta: Rineka Cipta.

Nurhaidah, T. T. (2016). Faktor-Faktor Penyebab Ketidaklengkapan Pengisian Rekam Medis Rawat Inap di Rumah Sakit. Jurnal Kedokteran Brawijaya Vol. 29, 261.

Ratman, D. (2013). Aspek Hukum Informed Consent Dan Rekam Medis Dalam Transaksi Terapeutik. bandung: Keni media.

Republik Indonesia (2009) Undang-undang Republik Indonesia Nomor 44 Tahun 2009, tentang Rumah Sakit

Republik Indonesia (2004) Undang-undang Republik Indonesia Nomor 29 Tahun 2004.

Rizkianita. (2018). Gambaran Self Efficacy Mobilisasi Pasien Pasca Bedah Di Ruang Zumar RSUD Al-Ihsan Balendah. Skripsi, diterbitkan, Politeknik Kesehatan Kementrian Bandung. Bandung.

Rusdiana, Ahyar. (2017). Tinjauan Kelengkapan Pengisian Persetujuan Tindakan Kedokteran Pasien Bedah Rawat Inap Di Rumah Sakit Umum Pusat Persahabatan, Medicordhif.

Samosir, A. (2017). Karya tulis ilmiah :Rekam medis dan informasi kesehatan Jendral Ahmad yani Yogyakarta. Tinjauan Kelengkapan Pegisian Informed Consent Rawat Inap di RSUD Prambanan .

Sugiarsi, S. (2019). Instrumen dan Analisis data Penelitian Rekam medis dan Manajemen Informasi Kesehatan.

Sugiyono, P. D. (2010). Metode Penelitian Kuantitatif Kualitatif, Dan R\&D. Bandung: Penerbit Alfabeta.

Sukendar, A. H. (2016). Tanggung Jawab Rumah Sakit Atas Kelengkapan Informed Consent Pada Saat Operasi Di Rs Premier Jatinegara Jakarta. Soepra Jurnal Hukum Kesehatan, Vol. 2 / No. 2, 230 .

Tathagati, A. (2014). Step by Step Membuat SOP. Jakarta : Efata Publishing.

Ulfa, H. m. (2018). Analisa Kelengkapan Informed Consent Tindakan Operasi Di Rumah Sakit Sansani Pekanbaru. Jurnal INOHIM volume 6 No.1

Wirajaya, M. K. (2019). Faktor Faktor yang Mempengaruhi Ketidaklengkapan Rekam Medis Pasien Pada Rumah Sakit di Indonesia. Jurnal manajemen informasi kesehatan Indonesia (JMIKI), 159. 